\title{
A guilty pleasure: Tourist perspectives on the ethics of feeding whale sharks in Oslob, Philippines"
}

Authors Jackie A. Ziegler ${ }^{1}$ (jziegler@uvic.ca), Joshua N. Silberg ${ }^{2,3,4}$, Gonzalo Araujo33, Jessica Labaja $^{3}$, Alessandro Ponzo ${ }^{3}$, Rick Rollins ${ }^{1,5}$, Philip Dearden ${ }^{1}$

\section{Affiliations}

1) Marine Protected Areas Research Group, Department of Geography, University of Victoria, PO Box 3060 STN CSC, Victoria, BC V8W 3R4, Canada

2) School of Resource and Environmental Management, Simon Fraser University, TASC 1Room\#8405, 8888 University Dr., Burnaby, BC V5A 1S6, Canada

3) Large Marine Vertebrates Research Institute, Cagulada Compund, Barangay Tejero, Jagna, Bohol 6308, Philippines

4) Hakai Institute, PO Box 309, Heriot Bay, BC V0P 1H0, Canada

5) Vancouver Island University, 900 Fifth St., Nanaimo, BC V9R 5S5, Canada

\begin{abstract}
This study explored the ethics of provisioning wildlife to enhance tourist interactions at a whale shark tourism site in Oslob, Philippines. TripAdvisor comments $(\mathrm{n}=947)$ and tourist surveys ( $\mathrm{n}=761$ ) were used to better understand tourists' perceptions of whale shark provisioning in Oslob. The ethical decisions made were then critically assessed using utilitarian and animal welfare ethical philosophies. The majority of respondents supported whale shark provisioning, despite many being aware of the ethical complications of provisioning sharks for tourism purposes. Respondents justified their participation in this activity using mainly economic, human enjoyment, and animal welfare arguments. A utilitarian assessment of the potential costs and benefits of this activity highlighted the gaps in our knowledge regarding the economic and social benefits of this activity, as well as the negative impacts on the sharks' welfare. Until such analyses are completed, significant ethical questions remain regarding the provisioning of these sharks.
\end{abstract}

Keywords wildlife provisioning, sharks, marine wildlife tourism, tourism ethics, conservation, tourist perceptions, TripAdvisor

\footnotetext{
* This is a post-print version of the following article, please cite as follows: Ziegler, J.A., Silberg, J.N., Araujo, G., Labaja, J., Ponzo, A., Rollins, R., \& Dearden, P. (2018). A guilty pleasure: Tourist perspectives on the ethics of feeding whale sharks in Oslob, Philippines. Tourism Management 68: 264-274. Link to original article: https://doi.org/10.1016/j.tourman.2018.04.001
} 


\section{Introduction}

An emerging concern in marine wildlife tourism (MWT) is the ethics of tourism activities that involve the provisioning of animals. Provisioning or feeding wild animals is becoming more pervasive in MWT, especially for ray and shark diving activities (Brena, Mourier, Planes, \& Clua, 2015; Burgin \& Hardiman, 2015; Gallagher et al., 2015). The practice is controversial as the longterm impacts of provisioning marine wildlife remain unclear (Hammerschlag, Gallagher, Wester, Luo, \& Ault, 2012; Gallagher et al., 2015; Patroni, Simpson, \& Newsome, in press). Provisioning enhances the tourism draw, since operators can guarantee close interactions with otherwise elusive wild animals (Newsome \& Rodger, 2008; Orams, 2002; Patroni et al., in press), thereby improving the economic viability of the site and providing an enhanced incentive for protection. However, there are also potential costs to the focal species and ecosystem (Corcoran et al., 2013; Burgin \& Hardiman, 2015; Gallagher et al., 2015; Parsons, 2012; Rizzari, Semmens, Fox, \& Huveneers, 2017). Only one study to date has assessed tourists' support for provisioning sharks or rays within MWT (Semeniuk, Haider, Beardmore, \& Rothley, 2009); none have assessed tourists' ethical perceptions of such provisioning activities, despite a need for more studies exploring the social perspective of provisioning activities (Patroni et al., in press). The goals of the current study were to assess tourists' support of provisioning activities at a MWT site and to gain a better understanding of tourists' ethical considerations when participating in such activities. The next section provides some context on ethics within wildlife tourism. This is followed by an introduction to the case study and the specific study objectives.

\section{Ethics in wildlife tourism}

Studies assessing the ethical implications of wildlife tourism activities have only emerged in the last two decades (Fennell, 2015a). There are several ethical philosophies that can be applied to wildlife tourism interactions (see Fennell, 2015b for a review). Animal welfare is an ethical philosophy interested in the welfare of individual animals (Fennell, 2015b). Individual animals are afforded some level of moral considerability, although they are not necessarily afforded the same status as humans (Fennell, 2015b; Garrod, 2007). For example, it can be argued using this position that the harming of an individual animal through tourism activities is morally acceptable provided it is outweighed by benefits to humans.

Utilitarianism, on the other hand, is an ethical philosophy that requires that all costs and benefits of a given action be considered and the correct action is the one providing the greatest good to the greatest number of interests (Dobson, 2011). Although utilitarianism requires that all 
interests (human and animal) receive equal consideration, it does not require equal treatment; thus, humans may be given preference over animals due to their higher capacity to suffer (Dobson, 2011; Singer, 1995). Applying this theory to wildlife tourism, potential benefits of wildlife tourism include human enjoyment, education, funding for conservation, economic incentives to protect a species and or environment, scientific research, instilling a conservation ethic in participants, and community social and economic benefits (Ardoin, Wheaton, Bowers, Hunt, \& Durham, 2015; Ballantyne, Packer, \& Falk, 2011; Ballantyne, Packer, \& Hughes, 2009; Bentz, Dearden, Ritter, \& Calado, 2014; Brooks, Waylen, \& Mulder, 2013; Brunnschweiler, 2010; Camp \& Fraser, 2012; Catlin, Hughes, Jones, Jones, \& Campbell, 2013; Cisneros-Montemayor, Barnes-Mauthe, AlAbdulrazzak, Navarro-Holm, \& Sumaila, 2013; Clua, Buray, Legendre, Mourier, \& Planes, 2011; Dobson, 2011; Filby, Stockin, \& Scarpaci, 2015; Higham \& Lusseau, 2007; 2008; Hill, Byrne, \& Pickering, 2015; Lück, 2003; Mayes, Dyer \& Richins, 2004; Mintzer et al., 2015; Newsome, Lewis, \& Moncrieff, 2004; O’Malley, Lee-Brooks, \& Medd, 2013; Orams, 2002; Parsons, 2012; Pegas, Coghlan, Stronza, \& Rocha, 2013; Powell \& Ham, 2008; Reynolds \& Braithwaite, 2001; Tisdell \& Wilson, 2001; Topelko \& Dearden, 2005; Vianna, Meekan, Pannell, Marsh, \& Meeuwig, 2012; Waylen, McGowan, \& Milner-Gulland, 2009; Wilson \& Tisdell, 2003). The costs of wildlife tourism activities include negative impacts on the focal species, other wildlife, tourists, and potentially the local community (Archer, Cooper, \& Ruhanen, 2005; Burgin \& Hardiman, 2015; Dubois \& Fraser, 2013; Gallagher et al., 2015; Higham, Bejder, Allen, Corkeron, \& Lusseau, 2016; Parsons, 2012; Rizzari et al., 2017; Patroni et al., in press; Walpole \& Goodwin, 2001). Using a utilitarian approach, one could argue that a MWT activity with legitimate conservation outputs (e.g., money from ticket sales is used to create a marine protected area for the focal species), but poor animal welfare conditions, is acceptable (Dobson, 2011; Moorhouse, D'Cruze, \& MacDonald, 2017) since "it produces or intends to produce at least as great a balance of good over bad" (Fennell, 2015b, p.33). Tourism activities in which none of the revenue is invested in conservation, animal welfare, or local communities, would be considered an exploitation of the focal species for profit (Moorhouse et al., 2017).

Moorhouse, Dahlsjö, Baker, D'Cruze, \& Macdonald (2015) assessed the impacts of twentyfour wildlife tourism attractions on animal welfare and conservation and compared these results to tourists' feedback on TripAdvisor. The authors found that six tourism attractions had a net positive impact, while the rest had net negative conservation and/or welfare impacts; however, only $7.8 \%$ of all tourist feedback on these activities was negative due to conservation or animal welfare 
concerns. The authors concluded that millions of tourists are participating in wildlife tourism activities that are detrimental to the animals involved but only a small percentage of tourists realize it and/or care (Moorhouse et al., 2015).

In the absence of any standardised global wildlife welfare laws or standards of practice for wildlife tourism attractions (Patroni et al., in press), tourist dollars become the ultimate judge of what constitutes acceptable use of animals at wildlife tourism sites, and thus animal welfare standards become subject to market forces (Moorhouse et al., 2017). If tourists have a negative experience and tell other potential tourists, it is possible that tourism numbers and revenue will decline leading to improved ethical standards or the closing of the site (Moorhouse et al., 2017). However, such feedback would not occur if tourists could not perceive negative welfare impacts, could not communicate their concern to others, or if they felt that the poor welfare conditions did not sufficiently detract from their enjoyment of the tourism attraction (Moorhouse et al., 2017). For example, Moorhouse et al. (2015) found that only a minority of tourists were aware of welfare issues at tourism sites; even attractions with the worst animal welfare conditions had over $80 \%$ positive reviews on TripAdvisor.

In some cases, tourists are simply ignorant of any ethical issues of a given wildlife tourism activity and therefore are not making a moral decision (Moorhouse et al., 2017). A number of studies, however, have shown that unethical behaviour is often due to behaviours people do not recognize as unethical due to "systematic and predictable ethical blind spots" (i.e., "bounded ethicality"; Sezer, Gino, \& Bazerman, 2015, p.77). One such blind spot occurs due to tension between the "want self" and the "should self" - i.e., between the side that wants instant gratification and the side that wants to make ethical decisions (Sezer et al., 2015). In this case, people think they will behave more ethically in accordance with their "should self" before making a decision, but when it actually comes time to make that decision, the "want self" takes over (Tenbrunsel, Diekmann, Wade-Benzoni, \& Bazerman, 2010). Termed “ethical fading”, this occurs because the immediate reward from the unethical behaviour becomes much more important in the moment and the ethical implications much less so (Sezer et al., 2015; Tenbrunsel \& Messick, 2004). Once the decision is made, however, the ethical implications come back to the forefront as the "should self" re-emerges and people attempt to reduce the cognitive dissonance stemming from the contradiction between their values and their actions (Sezer et al., 2015) by avoiding or disguising the moral implications of their actions (Tenbrunsel \& Messick, 2004) or by downplaying the consequences or justifying their actions (Curtin \& Wilkes, 2007; Juvan \& 
Dolnicar, 2014; Juvan, Ring, Leisch, \& Dolnicar, 2016). For example, Curtin (2006) and Curtin and Wilkes (2007) assessed the ethical perceptions of tourists who swam with dolphins, both in the wild and in captivity. They found that both groups enjoyed the experience; however, those who swam with wild dolphins had a greater ethical concern for dolphins kept in captivity, while those who swam with captive dolphins exhibited cognitive dissonance. The latter group alleviated their cognitive dissonance by focusing on the positives of the experience and denying the negatives (e.g., the dolphins looked happy, better than circus shows; Curtin, 2006; Curtin \& Wilkes, 2007). Shani (2009), meanwhile, examined the ethical perceptions of tourists who visited various captive wildlife tourism attractions (aquaria, zoos, safari or wildlife parks, animal theme parks, rodeos, bullfights, animal circus, animal racing) and found that tourists alleviated their cognitive dissonance by increasing their level of agreement with various justifications for a given attraction's existence. For example, a belief that captive animals were better off than animals in the wild may reduce the cognitive dissonance of watching wild animals perform unnatural tricks (Shani, 2009).

Moorhouse et al. (2017) identified three main reasons why tourists may be particularly susceptible to ethical blind spots when participating in wildlife tourism activities. First, tourists have a desire to escape from everyday life while on holiday and therefore may not apply the same ethical considerations in making decisions while on vacation that they would at home (e.g., Barr, Shaw, Coles, \& Prillwitz, 2010; Ganglmair-Wooliscroft \& Wooliscroft, 2017; Juvan \& Dolnicar, 2014). Second, tourists may not understand nor be able to assess the negative impacts their participation in a given tourism activity can have on the focal species' welfare and may assume that a given attraction would not be able to operate if it were unethical (Moorhouse et al., 2017). Third, they may feel reassured that a given activity is morally acceptable due to the large number of people present at some of these wildlife tourism attractions (Gino \& Galinsky, 2012; Moorhouse et al., 2017).

\section{Study objectives}

In the last five years, a handful of sites in the Philippines and Indonesia have started provisioning whale sharks to facilitate tourist interactions (Thomson et al., 2017). Whale shark tourism is viewed as a means of protecting the endangered whale shark (IUCN Red List; Pierce \& Norman, 2016) by providing economic incentives for their protection (Graham, 2004). Concern over the ethics of feeding an endangered, highly mobile animal for tourism purposes has led to a disagreement within the conservation community over whether or not this activity should be allowed to continue (Hammerschlag et al., 2012). To date, no one has examined tourists' ethical 
considerations when participating in this type of activity, nor critically examined the justifications for supporting such activities. However, many scholars have highlighted the need for more studies investigating the ethical views and perceptions of visitors to wildlife tourism attractions (Bach \& Burton, 2017; Davey, 2007; Frost \& Roehl, 2007; Jiang, Lück, \& Parsons, 2007; Moorhouse et al., 2017; Patroni et al., in press). The aim of the current study was to address this knowledge gap by assessing tourists' ethical perceptions of whale shark provisioning activities in Oslob, Philippines, to understand why they participated, as well as using utilitarian and animal welfare ethical philosophies to evaluate the justifications provided for supporting such activities.

\section{Methods}

\section{Study site}

Whale shark tourism in Oslob was first established in 2011 and has rapidly grown into one of the most visited whale shark tourism sites in the world. Unlike sites with seasonal whale shark tourism activities based on natural variation in nutrient availability (e.g., Mexico, Australia, Mozambique; Catlin \& Jones, 2010; de la Parra et al., 2011; Pierce, Méndez-Jiménez, Collins, \& RoseroCaicedo, 2010), whale sharks in Oslob are provisioned and therefore activities occur year-round (Thomson et al., 2017). Over 180,000 tourists visited the site in 2015, spending a minimum of US\$5 million (Thomson et al., 2017).

Oslob is a municipality on the southern end of the island of Cebu (Figure 1). Cebu lies in the Bohol Sea, one of the main sites for whale shark hunting in the Philippines in the decades prior to the 1998 federal ban, implemented in response to international outcry over the slaughter of whale sharks in Donsol, Philippines (Alava, Yaptinchay, Dolumbaló, \& Truno, 2002). However, fishermen in Oslob never hunted whale sharks. Instead, they targeted small shrimp, locally known as uyap, to use for bait and direct human consumption. Whale sharks were also attracted to the uyap and interfered with the fishers' practices. In some areas, fishers threw rocks in the direction of the whale sharks to scare the sharks away from the bait. Fishers in Tan-awan, a village in Oslob, used a different tactic - they lured the sharks away from their fishing areas by throwing small amounts of uyap into the water. The whale sharks would follow the fishers out of the area, and the fishers would return to resume their fishing undisturbed.

By August 2011, foreign business owners and other tourism operators learned of this practice and began paying the local fishers to take them out to see the whale sharks. Through social 
media, local newspapers, and international articles, stories of these "friendly" whale sharks spread and whale shark tourism in Tan-awan began.
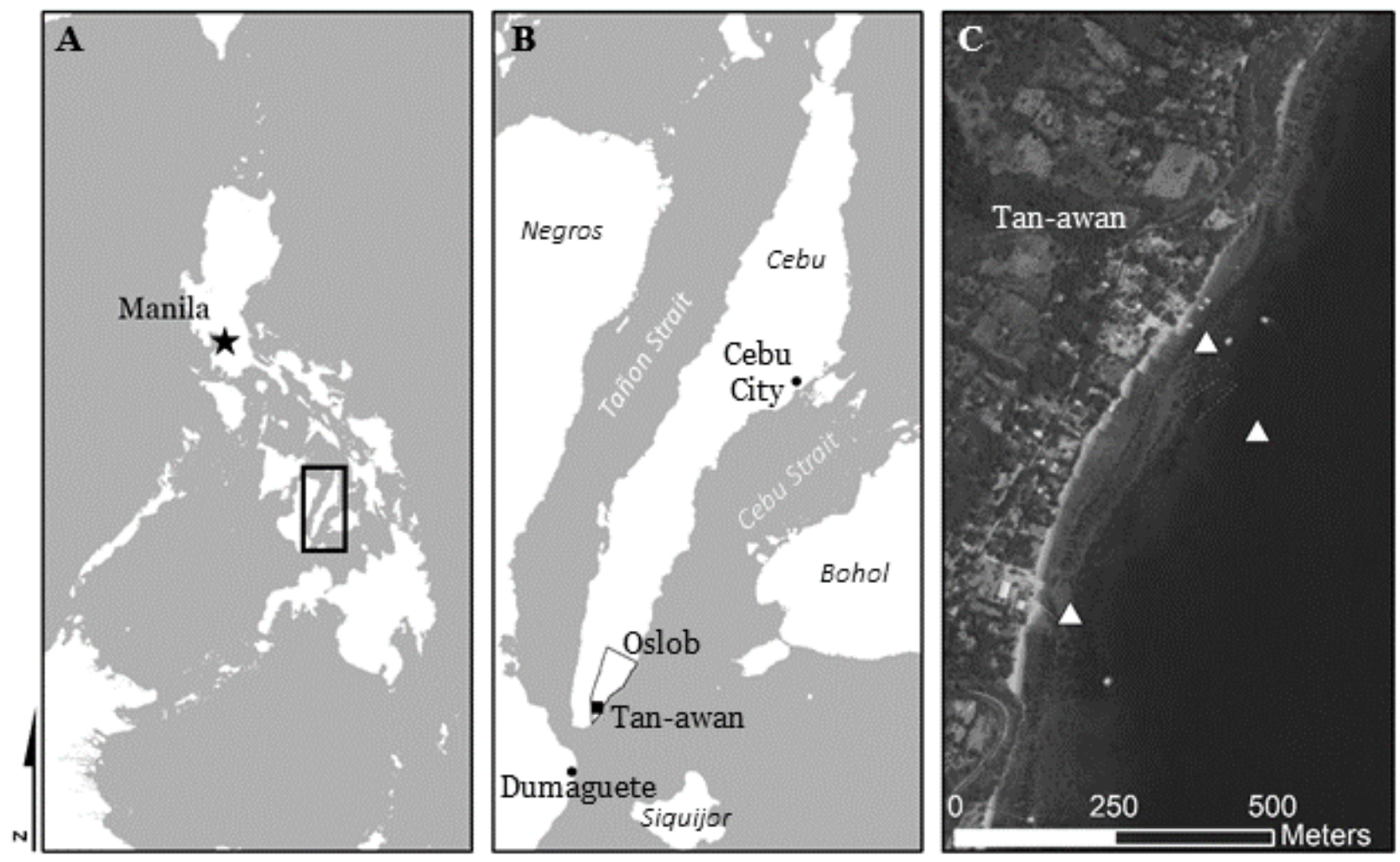

Figure 1. Map of study site. A. Location of the island of Cebu within the greater Philippine archipelago. B. Island of Cebu with the municipality of Oslob outlined. C. Whale shark viewing area in Tan-awan with the three buoys (triangle symbol) demarcating the interaction area.

Tourists receive a five-minute briefing prior to boarding paddleboats, which take them to the interaction area $50 \mathrm{~m}$ from shore (Figure 1C). The tourist boats tie up to each other and form a line. Tourists have the choice to remain in the boat or enter the water and swim with the sharks. Many hold on to the paddleboat's outriggers rather than swim freely in the interaction area (Figure 2). Feeder boats paddling parallel to this line feed the sharks to encourage them to swim past the waiting tourists. SCUBA diving is also possible at this site. Sharks are fed between 50 and $150 \mathrm{~kg}$ of uyap per day between 6AM and 1PM (Araujo et al., 2014). 


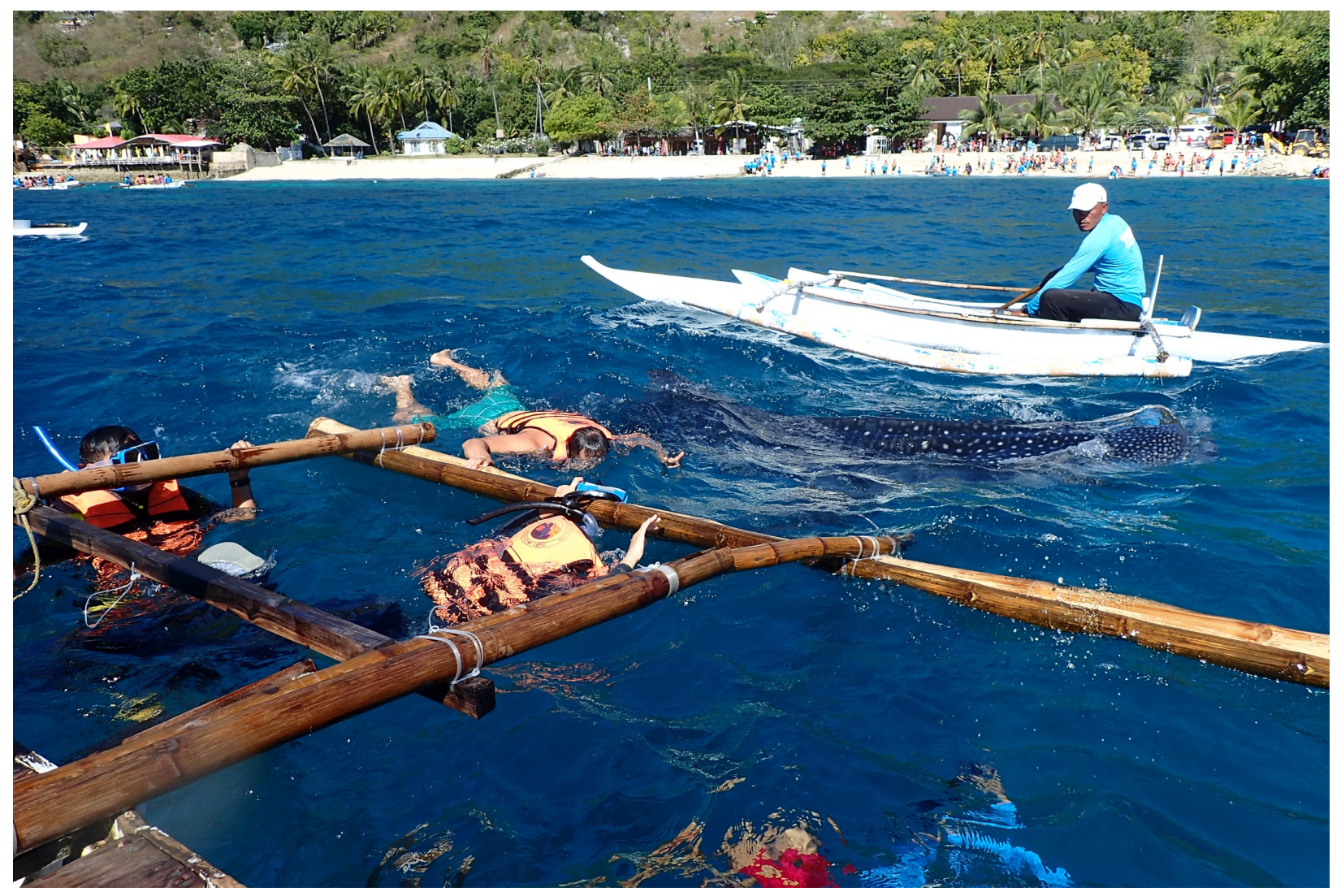

Figure 2. Feeder boat with whale shark passing by tourists in Oslob, Philippines.

\section{Data Analysis}

Two main data sources were used to address the research questions - participant surveys and TripAdvisor reviews.

Survey design and analysis

Surveys were opportunistically distributed to tourists as they returned to shore from the whale shark tour from May to October 2014. A total of 761 surveys were collected. This sample size is large enough to ensure a margin of error of $5.0 \%$ at the $95 \%$ confidence level (Vaske, 2008). This survey included questions regarding overall satisfaction with the experience, tourists' opinions about whale shark provisioning, willingness to pay for the whale shark experience, and sociodemographics. Questions were refined following an initial pilot test of the survey in 2013.

Satisfaction with the overall experience was measured using a five-point Likert scale with 1 being "very unsatisfied" and 5 "very satisfied". Respondents' willingness to return was measured using a five-point Likert scale from 1 "very unlikely" to 5 "very likely", while their willingness to recommend the tour was measured using a "yes/no" dichotomous rating. Tourist support for whale 
shark provisioning was measured using a five-point Likert scale ranging from 1 "strongly against" to 5 "strongly supportive", as well as an option for "I do not know/I am not sure". Willingness to pay for the whale shark experience was measured by asking respondents how much they would be willing to pay for provisioned and non-provisioned whale shark tours with different likelihoods of seeing whale sharks (i.e., $25 \%, 50 \%, 75 \%$ and $100 \%$ for non-provisioned tours and $100 \%$ for provisioned tours). Responses were compared by nationality.

\section{TripAdvisor analysis}

TripAdvisor comments were used to help understand the ethical decision-making of tourists. A total of 947 TripAdvisor reviews were extracted from the first posting in March 2012 until the end of January 2016 (TripAdvisor, 2016) and coded into NViVO 10 (QSR International, 2016). Following the methodology in Moorhouse et al. (2015), reviews with scores of 4 or 5 were considered supportive of whale shark tourism activities in Oslob, while those with scores of 1 or 2 were considered negative and not supportive of these tourism activities. Unlike Moorhouse et al. (2015), reviews with a score of 3 were kept in the analysis and considered to represent a neutral stance towards whale shark tourism activities in Oslob.

Reviews mentioning ethical concerns ( $\mathrm{N}=254$ ) were then classified into three subcategories based on the overall score provided. Those expressing ethical concerns but with an overall positive review (i.e., 4 or 5 star rating) were classified into the "guilty pleasure" category, while those giving a negative review (i.e., 1 or 2 star rating) due to ethical concerns were classified into the "regretful participation" category. Those with a score of 3 were classified as "neutral". Those comments that included justifications for participating in the activity despite knowing of the ethical issues with provisioning activities $(\mathrm{N}=138)$ were coded for up to 8 possible themes (e.g., economic benefits, animal welfare, human enjoyment).

The demographics of TripAdvisor reviewers are not representative of the tourists who visit Oslob. The majority of whale shark tour participants in Oslob are national tourists based on the local government logbooks (63\%, Figure 3$)$, while the comments posted were mostly from foreign tourists (72.9\%). Furthermore, people who post on TripAdvisor may not be typical of all tourists who visit the site. Sampling bias may therefore be an issue in terms of over- or undersampling certain tourist segments. However, the TripAdvisor data does allow the analysis of unsolicited reviews of the tourism experience and therefore may be able to identify areas of concern not included in a traditional survey format. 


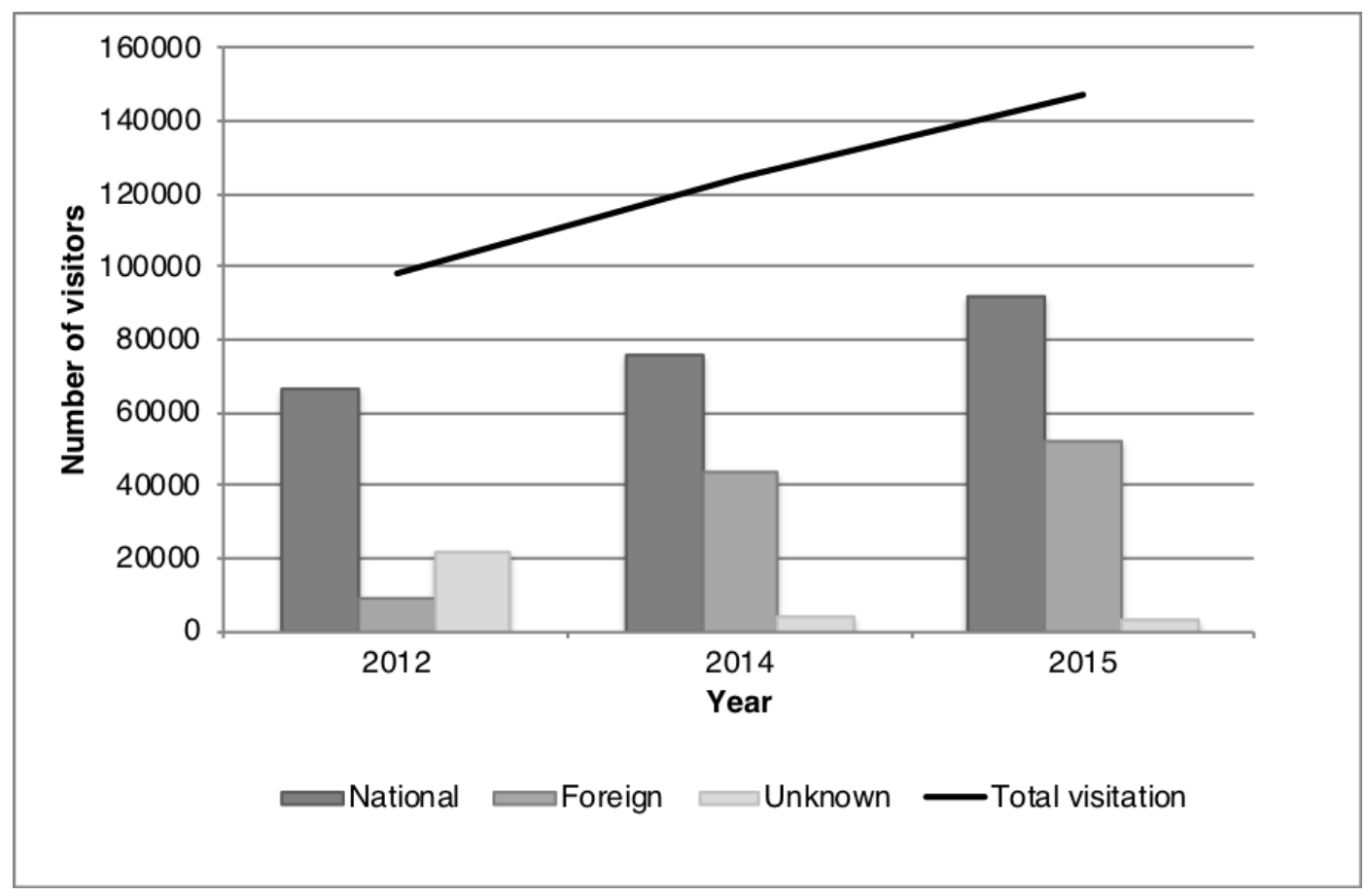

Figure 3. Annual visitation in Oslob, Philippines, by tourist type. Data from 2013 was omitted due to missing data from local government logbooks for this time period.

\section{Results}

\section{Survey}

The majority of respondents were young (57.3\%, 18-30), foreign (52.4\%), women (54.0\%), of low annual income $(51.4 \%,<\mathrm{US} \$ 15,000)$ with little to no experience shark watching $(79.4 \%$ selfclassified as novice/intermediate) and without any scuba certification (66.8\%). Most respondents only spent one day in Oslob (76.2\%) and would not have visited Oslob if whale sharks were not present (76.4\%). Foreign tourists were significantly less likely to have gone to Oslob if no whale sharks were present compared to national tourists $\left(85.6 \%\right.$ vs. $68.7 \% ; \chi^{2}(2, \mathrm{~N}=701)=29.587$, $\mathrm{p}=0.000$, Cramer's $V=0.205$ ). The Cramer's V effect size of 0.205 suggests that the strength of this difference is minimal to typical (Vaske, 2008).

\section{Satisfaction}

Overall, respondents were satisfied with the whale shark tourism experience in Oslob $(\mathrm{M}=4.1)$. Foreign tourists, however, were significantly less likely to be willing to participate in whale shark tourism in Oslob again $(62 \%)$ compared to national tourists $\left(90 \% ; \chi^{2}(1, \mathrm{~N}=632)=67.686, \mathrm{p}=0.000\right.$, Cramer's $V=0.327$ ). The Cramer's V effect size of 0.327 suggests that the strength of this difference is typical to substantial (Vaske, 2008). The vast majority of both foreign (93\%) and 
national (99\%) tourists would still recommend the tour, although foreign tourists were significantly less likely to do so $\left(\chi^{2}(1, \mathrm{~N}=632)=18.200, \mathrm{p}=0.000\right.$, Cramer's $\left.V=0.170\right)$. The Cramer's V effect size of 0.170 suggests that the strength of this difference is minimal to typical (Vaske, 2008).

Support for provisioning

Respondents were then asked whether or not they supported whale shark provisioning activities in Oslob. Nearly half of respondents were supportive of whale shark provisioning (48.6\%), while $13.2 \%$ were against such activities and $38.2 \%$ were neutral or unsure (Table 1). Foreign tourists were significantly less likely to support the feeding of whale sharks than national tourists (35\% vs. $65 \%$ ), with a further $47 \%$ and $26.9 \%$ neutral or unsure, respectively (Table 2). The Cramer's V effect size of 0.295 suggests that the strength of this difference is minimal to typical (Vaske, 2008). Table 1. Support for whale shark provisioning in Oslob.

\begin{tabular}{lcc}
\hline SuPPORT FOR PROVISIONING & FREQUENCY & PERCENT (\%) \\
\hline Strongly against & 28 & 3.9 \\
Against & 67 & 9.3 \\
Neutral & 207 & 28.8 \\
Supportive & 221 & 30.7 \\
Strongly supportive & 129 & 17.9 \\
Don't know & 68 & 9.4 \\
\hline
\end{tabular}

Note: Mean, 3.55; sd, 1.05 . 
Table 2. Support for whale shark provisioning in Oslob by nationality.

\section{PERCENT RESPONSE}

SUPPORT FEEDING \begin{tabular}{rl|lll|l|l|} 
National Foreign & Total response (N) & df & $x^{2}$ & $\boldsymbol{p}$ & Cramer's $V$
\end{tabular}

\begin{tabular}{|c|c|c|c|c|c|c|c|}
\hline Yes & 64.5 & 35.0 & 311 & 2 & 55.209 & $0.000^{*}$ & 0.295 \\
\hline No & 8.6 & 18.0 & 86 & & & & \\
\hline Neutral/not sure & 26.9 & 47.0 & 238 & & & & \\
\hline
\end{tabular}

*Significant at $\alpha=0.05$.

Respondents were also asked how much they would be willing to pay for a whale shark experience, both provisioned and non-provisioned with different percent likelihoods of seeing a shark (Table 3). Foreign tourists were willing to pay the most for an experience where sharks were not fed, but there was a 100\% chance of seeing a shark (US\$64), followed by sharks not fed with a $75 \%$ chance of seeing sharks (US\$45). National tourists on the other hand were willing to pay US\$17 for an experience where there was a 100\% chance of seeing a shark regardless of whether the sharks were fed (Table 3). The point biserial correlation effect sizes of 0.297 to 0.427 suggest that the strength of these differences is typical to substantial (Vaske, 2008).

Table 3. Willingness to pay for different whale shark encounter types by nationality (in USD).

\section{ENCOUNTER TYPE}

Amount (MEAN \pm SE)

National Foreign $\quad t \quad$ df $\quad p \quad r_{p b}$

\section{Provisioned}

$100 \%$ chance of seeing whale shark

$17.70 \pm 1.66$

$42.58 \pm 3.50$

$-6.417$

279.604

$0.000 * \quad 0.312$

\section{Not provisioned}

$\begin{array}{lccccccc}25 \% \text { chance of seeing whale shark } & 7.83 \pm 2.18 & 23.32 \pm 2.29 & -4.898 & 224.213 & 0.000 * & 0.297 \\ 50 \% \text { chance of seeing whale shark } & 10.17 \pm 2.23 & 31.46 \pm 2.61 & -6.204 & 237.513 & 0.000 * & 0.359 \\ & & & & & & & \\ 75 \% \text { chance of seeing whale shark } & 13.51 \pm 2.85 & 44.45 \pm 3.54 & -6.807 & 247.602 & 0.000 * & 0.381 \\ 100 \% \text { chance of seeing whale shark } & 17.15 \pm 2.75 & 63.69 \pm 4.77 & -8.453 & 264.233 & 0.000 * & 0.427\end{array}$

*Significant at $\alpha=0.05$. 


\section{TripAdvisor analysis}

Satisfaction with experience

TripAdvisor commenters' satisfaction with the whale shark tourism activities in Oslob was assessed using the provided star rating. The vast majority of comments were positive (i.e., score of 4 or $5 ; 86.8 \%$ ) with only $6.4 \%$ negative comments (i.e., score of 1 or 2 ) (Table 4 ). The mean star rating of the Oslob whale shark experience was $4.4 \pm 1.0$ and the mode was 5 .

Table 4. TripAdvisor star rating for whale shark tourism in Oslob.

\begin{tabular}{ccc} 
TripAdVISOR SCORE & FreQUeNCY & PERCENT (\%) \\
\hline 1 & 40 & 4.2 \\
2 & 21 & 2.2 \\
3 & 64 & 6.8 \\
4 & 261 & 27.6 \\
5 & 540 & 59.2 \\
\hline
\end{tabular}

Note: Mean, 4.4; sd, 1.00.

\section{Ethical concerns}

TripAdvisor comments mentioning ethical issues with this activity were coded and classified. Ethical concerns were mentioned in $27.2 \%(\mathrm{~N}=254)$ of all TripAdvisor reviews analysed. The TripAdvisor analysis identified three types of commenters concerned with the ethical nature of whale shark provisioning in Oslob. The "guilty pleasure" group was aware of the moral and ethical issues of provisioning a threatened species for tourism purposes, but still chose to do the tour and recommended it to others (i.e., a score of 4 or 5; Table 5).

"We appreciate that this is a controversial practice and we had mixed feelings before we began, but wanted to judge for ourselves. The concerns which have been raised by others are entirely legitimate [...] as an experience, however, it was incredible. Being so close to these beautiful, amazing creatures was unreal and is a memory we will hold dear for years to come." 
Ethical concerns were either voiced as unease with the potentially negative impacts to the animal welfare of the sharks visiting Oslob or couched within justifications for why such tourism activities should exist.

Table 5. Classification breakdown of TripAdvisor comments concerned with the ethics of provisioning whale sharks.

\begin{tabular}{lcc}
\hline Classification & Frequency & Percent (\%) \\
\hline Guilty pleasure & 173 & 68.1 \\
Regretful participation & 47 & 18.5 \\
Neutral & 34 & 13.4 \\
\hline
\end{tabular}

The "regretful participation" group were aware of the ethical issues and did not recommend the tour to others (i.e., score of 1 or 2).

"I feel like such a hypocrite for leaving this review but I must say, now that I have seen it first hand, I now know that it is a great injustice to the animals [...] I'm sure there are safer, and better ways to see them in their natural habitat without hurting them."

The "neutral" group also mentioned ethical concerns with participating in this activity, but were unsure or neutral regarding whether or not to recommend it to others (i.e., score of 3 ).

"Having such intimate interaction with such mammals [sic] [is] indeed a very amazing experience. However in order to have such interaction, we have to feed them. [...] I will not say this activity is right or wrong. I am not a moral police. I will let you decide."

TripAdvisor commenters' justifications for participating in the whale shark provisioning activities in Oslob were classified in order to gain a better understanding of the ethical decisions being made (Table 6). The primary justifications provided were the fact that the whale sharks were free to leave the provisioning area ("the whale sharks are free to come and go as they please"), human enjoyment ("wanted to see them in the wild, but there was no guarantee that we would see them so we gave in and glad we did"), provision of economic incentive to protect the sharks ("I 
prefer that to hunting sharks or whales"), and improved livelihoods and or wellbeing of the local community ("this brings money to the village").

Table 6. Classification of justifications used to support whale shark provisioning activities in Oslob.

\begin{tabular}{lcc}
\hline JustifiCATION & FREQUENCY & PERCENT (\%) \\
\hline Sharks are free to leave & 68 & 26.8 \\
Human enjoyment & 54 & 21.3 \\
Economic benefit to local community & 44 & 17.3 \\
Provides economic incentive to protect whale sharks & 41 & 16.1 \\
Well-regulated and enforced & 37 & 14.6 \\
Sharks are happy/healthy & 27 & 10.6 \\
Equivalent to keeping animals in zoo/aquaria & 6 & 2.4 \\
Fed only small amount & 6 & 2.4 \\
\hline
\end{tabular}

\section{Discussion}

\section{Assessing support for whale shark provisioning activities in Oslob}

When explicitly asked, a little under half of survey respondents supported the provisioning activities in Oslob and a further $40 \%$ were unsure or neutral. Foreign tourists were significantly less likely to support whale shark provisioning and willing to pay significantly more for a nonprovisioned whale shark experience compared to national tourists. However, the vast majority of both groups (>90\%) would recommend the tour to others. Based on Moorhouse et al.'s (2015) definition of support for a given ethically questionable wildlife tourism activity, anyone who provides a positive review is considered to support the unethical behaviour. Using this approach, over $90 \%$ of survey respondents supported feeding activities, tacitly or not, since they would recommend the tour to others. Similarly, TripAdvisor reviews were overwhelmingly positive $(86.8 \%)$, with only $5.4 \%$ of overall comments negative due to the ethical issues associated with this activity. 
Moorhouse et al. (2015) found that three quarters of wildlife tourism attractions assessed had net negative conservation and or welfare impacts, while only $7.8 \%$ of all tourist feedback on these activities was negative due to ethical concerns. The authors assessed the conservation status of a given wildlife tourism activity based on the IUCN Red List classification of the species of interest (i.e., activities targeting species considered vulnerable or near threatened on the IUCN Red List would be considered negative), while welfare was based on the 'five freedoms' of captive animals (i.e., negative status if only fulfills 2 to 3 of possible 5 freedoms). Based on these criteria, whale shark activities in Oslob would be considered to have a negative conservation status, since the whale shark is considered endangered on the IUCN Red List (Pierce \& Norman, 2016). The welfare status of whale sharks, on the other hand, is more difficult to assess. Whale sharks in Oslob are free from hunger and thirst, but whether they are free from discomfort, free from pain, injury or disease, free to express normal behaviours, or free from fear and distress is unclear. Apparent wildlife tolerance of human presence is not necessarily a sign that tourism activities are harmless to the focal species (Higham \& Shelton, 2011). Bejder, Samuels, Whitehead, Finn, \& Allen (2009) outlined three factors that can explain this apparent tolerance: (1) displacement - less tolerant individuals are displaced leaving more tolerant individuals at the site, (2) physiology physiological impairment prevents individuals from reacting to human presence, and (3) ecology - there is no suitable habitat to which the animals may relocate. Furthermore, some behaviours which may be perceived as positive interactions with humans (e.g., dolphins bowriding and leaping) may actually be under stimulus control (i.e., the presence of power boats is a stimulus not to rest) and not the result of choice (Higham \& Shelton, 2011). Understanding the short- and longterm impacts of whale shark provisioning activities is therefore critical to ensure that it is provides an overall positive conservation effect for the focal species.

A few studies have attempted to determine the impacts of provisioning activities on the sharks of Oslob. Schleimer et al. (2015) found that sharks at the site demonstrated both associative learning (i.e., associating the site with food and adapting their feeding behaviour) and habituation (i.e., increased tolerance levels in response to proximity to people and other sharks), which suggests that a combination of habituation and conditioning is changing whale shark behaviour while at the site. Araujo et al. (2014) concluded that differences in both residency and probability of being resighted of provisioned and non-provisioned whale sharks suggest that provisioning is leading to behavioural change in Oslob. Thomson et al. (2017) found that some whale sharks exhibited prolonged residency at the site and concluded that provisioning could influence foraging 
success, alter whale shark distributions and lead to dependency as the sharks get older. These findings suggest that the whale sharks are not completely free to exhibit normal behaviours. Assessing whether the whale sharks are free from pain, injury and stress, free from discomfort, and free from fear and distress is more difficult to determine in sharks and has not yet been assessed in Oslob, although studies are planned to better understand the physiological stress levels these animals undergo (G. Araujo, personal communication). Semeniuk, Bourgeon, Smith, \& Rothley (2009) successfully used physiological indicators to determine that fed stingrays at Stingray City Sandbar, Cayman Islands, were exhibiting symptoms of immunosuppression when compared to stingrays at non-tourist sites. The authors concluded that while there was no direct evidence of reduced survival at the site, the physiological parameters measured suggest that it is quite likely. In the face of the unknown welfare status of whale sharks at this site, a precautionary approach should be taken, especially considering this species is endangered, and a negative welfare status should be assumed until evidence is available to disprove it (Sorice, Shafer, \& Scott, 2003).

\section{Utilitarian assessment of the ethics of provisioning whale sharks for tourism purposes}

Tourists clearly weighed the pros and cons but let their desire to see the guaranteed, close sightings of whale sharks (i.e., their "want self", Sezer et al., 2015) guide their decision-making. Some comments explicitly stated this process; for example, "we were torn between the poor ecological aspect of this tourist place and our curiosity to see these amazing fish [...] curiosity was strongest". The ensuing cognitive dissonance from participating in an activity they knew to be unethical is evident in the justifications provided. Similar to Curtin (2006), who found that people who participated in captive swim-with dolphin tourism activities justified their actions by saying the dolphins looked happy and that it was better than circus shows, many TripAdvisor reviewers defended their participation in provisioned whale shark tourism activities in Oslob by arguing that this activity could not be that bad since the sharks seemed happy and were not being held captive; "the sharks are not stressed and are able to come and go, they just like a free meal [...] surely better than Seaworld?".

Dobson (2011) notes that any claims of benefits for a given tourism activity must be critically evaluated in order to determine if they are valid. If they are, then that activity can be deemed ethically valid from a utilitarian point of view as the suffering of the few is outweighed by the benefits of the activity to the many (Dobson, 2011). It is therefore necessary to determine if there are sufficient benefits of provisioning activities to the whale sharks and local community to justify the activity. Based on a literature review and justifications identified in the TripAdvisor 
analysis, the primary benefits of provisioned whale shark tourism activities in Oslob include human enjoyment, providing economic incentives to protect whale sharks and the greater environment, education, benefits to the local economy and community, and scientific research opportunities (e.g., tagging) (Apps, Dimmock, Lloyd, \& Huveneers, 2017; Brunnschweiler, 2010; Cisneros-Montemayor et al., 2013; Clua et al., 2011; Dobson, 2011; Filby et al., 2015; Higham \& Lusseau, 2007; 2008; Mayes et al., 2004; Orams, 2002; Pegas et al., 2013; Tisdell \& Wilson, 2001; Vianna et al., 2012; Wilson \& Tisdell, 2003; Zeppel \& Muloin, 2008a,b). Human enjoyment of the whale sharks is one of the primary benefits identified in this study with nearly $90 \%$ positive reviews on TripAdvisor and over $90 \%$ of survey respondents stating that they enjoyed the tour and would recommend it to others.

The main justification identified in the TripAdvisor analysis and provided for nonprovisioned whale shark tourism activities (Catlin et al., 2013; Graham, 2004) is that these activities generate economic benefits for the local communities thereby providing economic incentives to conserve the sharks rather than hunt them. This is a valid point. Although the fishermen participating in whale shark tourism in Oslob never hunted the whale sharks in their waters, whale sharks were recently uplisted from threatened to endangered on the IUCN Red List due to significant population declines in the Indo-Pacific linked to illegal harvesting (Pierce \& Norman, 2016). Li, Wang, \& Norman (2012) identified an emerging illegal harvest of these sharks in Chinese waters. In 2014, a factory in China was found to slaughter upwards of 600 whale sharks each year despite being a protected species in Chinese waters (Lee, 2014). A whale shark released from a fishing net in Taiwan travelled to Leyte, Philippines (Araujo et al., 2017a), a site known to share a degree of connectivity with Oslob (Araujo et al., 2014; 2017a), and therefore the whale sharks in the Philippines, including Oslob, may be part of the same population that is targeted by illegal fisheries in China.

The economic benefit from whale shark tourism is worth millions of dollars each year. Economic valuations for non-provisioned whale shark tourism sites range from US\$3.7 million in Belize (Graham, 2004) to US\$9.4 million in the Maldives (Cagua, Collins, Hancock, \& Rees, 2014) and US\$19 million in Australia (Huveneers et al., 2017). The provisioned activities in Oslob are worth an estimated US\$5 million to the local economy (Thomson et al., 2017) and have allowed for the socioeconomic development of the community. Prior to the start of these activities, many of the fishermen turned tour operators in Tan-awan were living off just US\$1 per day whereas now they can afford to put children and extended family through school, pay for hospital treatments for 
extended family, food, motorbikes and concrete homes (J. Ziegler, unpublished data). Villagers who had to leave Oslob in order to find jobs in Manila and other big cities were able to return home because of the job opportunities now present (J. Ziegler, unpublished data). Neighbouring villages are also benefitting from the increase in tourists participating in whale shark tours. For example, each household in neighbouring Bangcogon receives up to US\$25 per month from entrance fees for Sumilon, a marine reserve located across the bay from Tan-awan (J. Ziegler, unpublished data). Locals in the municipality of Oslob can also generate income from providing boat tours to Sumilon, motor-taxi services, restaurants, hotels, grocery stores, and selling souvenirs.

Whether the economic benefits generated from whale shark provisioning translate into conservation outcomes for the sharks is unknown. Whether a given tourism activity is successful in achieving its conservation goals is strongly influenced by the local context (Brockelman \& Dearden, 1990). For example, inequitable distribution of economic benefits from tourism activities can result in resentment and lack of support for these activities, as well as conflict over natural resources (Brooks et al., 2013; Hunt \& Stronza, 2011; Spiteri \& Nepal, 2006; Stem, Lassoie, Lee, Deshler, \& Schelhas, 2003). Even if benefits are equitably distributed, they may not always result in increased conservation support (e.g., Walpole \& Goodwin, 2001). In other cases, proconservation behaviours are a result of increased enforcement, not improved conservation awareness or attitudes (e.g., Mintzer et al., 2015). Furthermore, tourism activities may not include the most resource-dependent community members who are most likely to participate in negative extractive behaviours, thereby missing an opportunity to improve ecological conservation outcomes in the community (Mehta \& Kellert, 1998; Walpole \& Goodwin, 2001). Finally, the economic benefits generated from MWT activities may not be sufficient to discourage locals from participating in negative behaviours, such as unsustainable and or illegal resource extraction (Young, 1999). This type of in-depth socio-economic assessment is needed in Oslob in order to better understand who is benefitting from these tourism activities and who is not and the implications of potential inequities.

The significant money generated from these activities in Oslob may increase the whale shark tour operators' (and greater community's) interest in ensuring the sharks return every day and potentially lead to increased care for the wellbeing of the sharks and greater marine environment. However, at the moment, there is little incentive for the operators in Oslob to manage the growth of this site sustainably and ethically when the future of the local community's 
livelihood remains uncertain. A primary concern for the local community is the fact that the federal government of the Philippines has not yet decided whether provisioned whale shark tourism should be legal in the country and, if not, if Oslob will be grandfathered in as the only legal site for this activity. If shark provisioning is deemed illegal at the site, there is the potential for the whale sharks to disappear from Oslob waters since this site only had sporadic whale shark sightings prior to the commencement of provisioning activities (Thomson et al., 2017). Without whale sharks, Oslob's tourism draw is in question, with the majority of both foreign and national tourists stating that they would not have visited the site if the sharks were not present. Oslob is a rural community five hours from Cebu City by bus. Unless the community develops alternative tourist attractions that can compensate for a decline in tourist numbers due to dwindling whale shark numbers, the community is unlikely to see continued economic growth. Their motivation is therefore to make as much money as possible from this endeavour before it gets shut down and not on ensuring an ethical and sustainable tourism experience. Research is currently being conducted to better understand the link between the tour operators' participation in these tourism activities and conservation outcomes at this site.

Another potential benefit of this tourism activity is education as it is believed to lead to pro-conservation attitudes and behaviours post-trip (Apps, Dimmock, \& Huveneers, 2018; Dearden, Bennett, \& Rollins, 2007; Filby et al., 2015; Mayes et al., 2004; Orams, 1996; Zeppel \& Muloin, 2008a,b). However, the literature is inconclusive as to whether education at MWT sites actually leads to long-term changes in tourist attitudes or behaviours (Apps et al., 2018; Ardoin et al., 2015; Mayes et al., 2004; Packer \& Ballantyne, 2012; Powell \& Ham, 2008; Zeppel \& Muloin, 2008a,b). If education is to be used as a justification for provisioning, then it must be proven that there are beneficial consequences beyond the immediate experience (Dobson, 2011). In the case of Oslob, no interpretation is provided on the whale sharks beyond the 5-minute pre-interpretation talk outlining the rules of the encounter (i.e., do not touch shark, stay $4 \mathrm{~m}$ away, no flash photography). This type of information does not typically lead to changes in pro-conservation attitudes or behaviours (Apps et al., 2018; Jacobs \& Harms, 2014). Despite TripAdvisor reviews mentioning the potential educational benefit of this activity, research has found that simply participating in wildlife tourism without in-depth interpretation seldom results in educational benefits (Jacobs \& Harms, 2014). Educational value is therefore not currently a valid justification for allowing this type of activity in Oslob. 
Scientific research is also used to justify the value of wildlife tourism activities (Dobson, 2011). All of the scientific research being undertaken in Oslob is focused on understanding the impacts of provisioning on the whale sharks visiting the site (Araujo et al., 2014; Schleimer et al., 2015; Thomson et al., 2017). Photo-ID studies have found that some sharks found in Oslob can also be found at other tourism sites within the Philippines (Araujo et al., 2014; 2017a), which increases our knowledge of whale shark movements. However, the value of provisioning in improving scientific knowledge beyond studying impacts is limited and therefore may not represent a valid claim for support of the practice.

\section{Conclusion}

Based on this examination of potential benefits of provisioned whale shark tourism activities in Oslob, the most salient factors in deciding whether this activity is ethically valid using a utilitarian approach are the significant economic benefits to the local community, the human enjoyment of those participating in the activity, and the real and potential costs to the focal species. It is important to remember that utilitarianism does not require equal treatment (Dobson, 2011). It is therefore possible for a wildlife tourism attraction to focus on human benefits, including human enjoyment and economic benefits to the local community, over issues of species conservation and animal suffering (Dobson, 2011). Dobson (2011) states that distinguishing between "trivial" (i.e., beneficial but not necessary for avoidance of pain and suffering) and "urgent" (i.e., relate to avoidance of pain and suffering) interests can help address problems with wildlife tourism activities where humans enjoy the experience, but the animals suffer. In the case of whale sharks, an endangered species experiencing potential negative impacts from both provisioned (Araujo et al., 2014; Schleimer et al., 2015; Thomson et al., 2017) and non-provisioned (Anderson et al., 2014; Araujo, Vivier, Labaja, Hartley, \& Ponzo, 2017b; Haskell et al. 2014; Pierce et al., 2010; Quiros, 2007; Raudino et al., 2016) tourism activities and other currently unknown impacts (e.g., physiological stress from tourism activities, disease loads) and knowledge gaps regarding their ecology (e.g., migration, population connectivity, breeding/pupping locations, longevity; Rowat \& Brooks, 2012), the need to avoid any possibility of negative impacts should supersede the "trivial" benefits of human entertainment. However, the significant economic benefits to the local economy could also be considered an "urgent" interest to avoid suffering of the local community and may supersede the "urgent" needs of the whale sharks. A determination must be made as to whether the suffering prevented in the local community is more important than the suffering incurred by the whale sharks. Until the impacts of these activities are fully understood and the 
animal welfare status of this activity is fully assessed, a precautionary approach should be used, as the cost-benefit analysis required in a utilitarian approach cannot be realized without a complete picture of the ecological costs of the activity to the sharks.

The main critique of utilitarianism as an ethical approach is that it is nearly impossible to consider the interests of all humans and animals involved in a given wildlife tourism activity (Dobson, 2011). In Oslob, this would mean considering the interests of the whale sharks visiting Oslob, whale sharks in the wider population, all other marine animals both in Oslob and abroad, the animals in Oslob that depend on revenue of the tourism activity (i.e., their owners use money from tourism activity to buy them food, keep house, etc.), the local tour operators, their families, the local community and all those that receive economic benefits from the activity, and finally the tourists who come to see the sharks. Matheny (2006), however, states that any wildlife tourism activity that claims to have benefits for either humans or the focal species should be able to provide evidence that not only fully supports such claims, but also demonstrates that a thorough costbenefit analysis of the activity has taken place for all those who have an interest in the activity. This has not taken place in Oslob. Whale shark provisioning activities in Oslob should therefore, ipso facto, be considered unethical until such cost-benefit analyses are made.

Author contribution J. Ziegler led data analysis and manuscript preparation. J. Silberg led data collection and was involved in data analysis and manuscript review. J. Labaja was involved in data collection. A. Ponzo and G. Araujo were involved in site research, funding, data collection, and manuscript review. P. Dearden was involved with site research, funding, and manuscript review. R. Rollins was involved with manuscript preparation.

Acknowledgments We thank the LAMAVE volunteers for their hard work collecting the survey data, Dr. Joseph King for his invaluable guidance in the writing of the manuscript, Dr. Sarah Trimble for her help with the figures, as well as the two anonymous reviewers whose comments strengthened this manuscript. This work was supported by the Social Sciences and Humanities Research Council under Grant 435-2015-0600. 


\section{References}

Alava, M., Yaptinchay, A., Dolumbaló, E., Truno, R., 2002. Fishery and trade of whale sharks and manta rays in the Bohol Sea, Philippines, in: Fowler, S., Reed, T., Dipper, F. (Eds.), Elasmobranch Biodiversity, Conservation and Management, IUCN, pp. 132-148.

Anderson, D. J., Kobryn, H. T., Norman, B. M., Bejder, L., Tyne, J. A., \& Loneragan, N. R. (2014). Spatial and temporal patterns of nature-based tourism interactions with whale sharks (Rhincodon typus) at Ningaloo Reef, Western Australia. Estuarine, Coastal and Shelf Science, 148(5), 109-119.

Apps, K., Dimmock, K., Lloyd, D. J., \& Huveneers, C. (2017). Is there a place for education and interpretation in shark-based tourism? Tourism Recreation Research, 42(3), 327-343.

Apps, K., Dimmock, K., \& Huveneers, C. (2018). Turning wildlife experiences into conservation action: can white shark cage-dive tourism influence conservation behaviour? Marine Policy, $88,108-115$.

Araujo, G., Lucey, A., Labaja, J., So, C. L., Snow, S., \& Ponzo, A. (2014). Population structure and residency patterns of whale sharks, Rhincodon typus, at a provisioning site in Cebu, Philippines. PeerJ, 2, e543.

Araujo, G., Snow, S., So, C. L., Labaja, J., Murray, R., Colucci, A., \& Ponzo, A. (2017a).

Population structure, residency patterns and movements of whale sharks in Southern Leyte, Philippines: results from dedicated photo-ID and citizen science. Aquatic Conservation: Marine and Freshwater Ecosystems, 27(1), 237-252.

Araujo, G., Vivier, F., Labaja, J. J., Hartley, D., \& Ponzo, A. (2017b). Assessing the impacts of tourism on the world's largest fish Rhincodon typus at Panaon Island, Southern Leyte, Philippines. Aquatic Conservation: Marine and Freshwater Ecosystems, 27(5), 986-994.

Archer, B., Cooper C., \& Ruhanen, L. (2005). The positive and negative impacts of tourism, in: Theobald, W. F. (Ed.), Global Tourism (3rd Edition), Butterworth-Heinemann, pp.79-103.

Ardoin, N. M., Wheaton, M., Bowers, A. W., Hunt, C. A., \& Durham, W. H. (2015). Nature-based tourism's impact on environmental knowledge, attitudes, and behavior: a review and analysis of the literature and potential future research. Journal of Sustainable Tourism, 23(6), 838-858.

Bach, L., \& Burton, M. (2017). Proximity and animal welfare in the context of tourist interactions with habituated dolphins. Journal of Sustainable Tourism, 25(2), 181-197. 
Ballantyne, R., Packer, J., \& Falk, J. (2011). Visitors' learning for environmental sustainability: Testing short-and long-term impacts of wildlife tourism experiences using structural equation modelling. Tourism Management, 32(6), 1243-1252.

Ballantyne, R., Packer, J., \& Hughes, K. (2009). Tourists' support for conservation messages and sustainable management practices in wildlife tourism experiences. Tourism Management, 30(5), 658-664.

Barr, S., Shaw, G., Coles, T., \& Prillwitz, J. (2010). 'A holiday is a holiday': practicing sustainability, home and away. Journal of Transport Geography, 18(3), 474-481.

Bejder, L., Samuels, A., Whitehead, H., Finn, H., \& Allen, S. (2009). Impact assessment research: use and misuse of habituation, sensitisation and tolerance in describing wildlife responses to anthropogenic stimuli. Marine Ecology-Progress Series, 395, 177-185.

Bentz, J., Dearden, P., Ritter, E., \& Calado, H. (2014). Shark diving in the Azores: challenge and opportunity. Tourism in Marine Environments, 10(1-2), 71-83.

Brena, P. F., Mourier, J., Planes, S., \& Clua, E. (2015). Shark and ray provisioning: functional insights into behavioral, ecological and physiological responses across multiple scales. Marine Ecology-Progress Series, 538, 273-283.

Brockelman, W. Y., \& Dearden, P. (1990). The role of nature trekking in conservation: a casestudy in Thailand. Environmental Conservation, 17(2), 141-148.

Brooks, J., Waylen, K. A., \& Mulder, M. B. (2013). Assessing community-based conservation projects: A systematic review and multilevel analysis of attitudinal, behavioral, ecological, and economic outcomes. Environmental Evidence, 2(1), 2.

Brunnschweiler, J. M. (2010). The Shark Reef Marine Reserve: a marine tourism project in Fiji involving local communities. Journal of Sustainable Tourism, 18(1), 29-42.

Burgin, S., \& Hardiman, N. (2015). Effects of non-consumptive wildlife-oriented tourism on marine species and prospects for their sustainable management. Journal of Environmental Management, 151, 210-220.

Cagua, E. F., Collins, N. M., Hancock, J., \& Rees, R. (2014). Whale shark economics: a valuation of wildlife tourism in South Ari Atoll, Maldives. PeerJ, 2, e515. 
Camp, E., \& Fraser, D. (2012). Influence of conservation education dive briefings as a management tool on the timing and nature of recreational SCUBA diving impacts on coral reefs. Ocean \& Coastal Management, 61, 30-37.

Catlin, J., \& Jones, R. (2010). Whale shark tourism at Ningaloo Marine Park: a longitudinal study of wildlife tourism. Tourism Management, 31(3), 386-394.

Catlin, J., Hughes, M., Jones, T., Jones, R., \& Campbell, R. (2013). Valuing individual animals through tourism: science or speculation?. Biological Conservation, 157, 93-98.

Cisneros-Montemayor, A. M., Barnes-Mauthe, M., Al-Abdulrazzak, D., Navarro-Holm, E., \& Sumaila, U. R. (2013). Global economic value of shark ecotourism: implications for conservation. Oryx, 47(3), 381-388.

Clua, E., Buray, N., Legendre, P., Mourier, J., \& Planes, S. (2011). Business partner or simple catch? The economic value of the sicklefin lemon shark in French Polynesia. Marine and Freshwater Research, 62(6), 764-770.

Corcoran, M. J., Wetherbee, B. M., Shivji, M. S., Potenski, M. D., Chapman, D. D., \& Harvey, G. M. (2013). Supplemental feeding for ecotourism reverses diel activity and alters movement patterns and spatial distribution of the southern stingray, Dasyatis americana. PloS ONE, 8(3), e59235.

Curtin, S. C. (2006). Swimming with dolphins: a phenomenological exploration of tourist recollections. International Journal of Tourism Research, 8(4), 301-315.

Curtin, S., \& Wilkes, K. (2007). Swimming with captive dolphins: current debates and postexperience dissonance. International Journal of Tourism Research, 9(2), 131-146.

Davey, G. (2007). Public perceptions in urban China toward zoos and their animal welfare. Human Dimensions of Wildlife, 12(5), 367-374.

de la Parra Venegas, R., Hueter, R., Cano, J. G., Tyminski, J., Remolina, J. G., Maslanka, M., Ormos, A., Weigt, L., Carlson, B, \& Dove, A. (2011). An unprecedented aggregation of whale sharks, Rhincodon typus, in Mexican coastal waters of the Caribbean Sea. PloS ONE, 6(4), e18994.

Dearden, P., Bennett, M., \& Rollins, R. (2007). Implications for coral reef conservation of diver specialization. Environmental Conservation, 33(4), 353-363. 
Dobson, J. (2011). Towards a utilitarian ethic for marine wildlife tourism. Tourism in Marine Environments, 7(3-4), 213-222.

Dubois, S., \& Fraser, D. (2013). A framework to evaluate wildlife feeding in research, wildlife management, tourism and recreation. Animals, 3(4), 978-994.

Fennell, D. A. (2015a). Ethics in tourism, in: Moscardo, G., Benckendorff, P. (Eds.), Education for sustainability in tourism, CSR, Sustainability, Ethics \& Governance, pp. 45-57.

Fennell, D. A. (2015b). The status of animal ethics research in tourism: a review of theory, in: Markwell, K. (Ed.), Animals and Tourism: Understanding diverse relationships, Channel View Publications, pp. 27-43.

Filby, N. E., Stockin, K. A., \& Scarpaci, C. (2015). Social science as a vehicle to improve dolphinswim tour operation compliance? Marine Policy, 51, 40-47.

Frost, W., \& Roehl, W. S. (2007). Zoos, aquaria, and tourism. Tourism Review International, 11(3), 191-196.

Gallagher, A. J., Vianna, G. M., Papastamatiou, Y. P., Macdonald, C., Guttridge, T. L., \& Hammerschlag, N. (2015). Biological effects, conservation potential, and research priorities of shark diving tourism. Biological Conservation, 184, 365-379.

Ganglmair-Wooliscroft, A., \& Wooliscroft, B. (2017). Ethical behaviour on holiday and at home: combining behaviour in two contexts. Journal of Sustainable Tourism, 25(4), 589-604.

Garrod, B. (2007). Marine wildlife tourism and ethics, in: Higham, J., Lück, M. (Eds.), Marine Wildlife and Tourism Management, CABI, pp. 257-271.

Gino, F., \& Galinsky, A. D. (2012). Vicarious dishonesty: when psychological closeness creates distance from one's moral compass. Organizational Behavior and Human Decision Process, $119(1), 15-26$.

Graham, R. T. (2004). Global whale shark tourism: a "golden goose" of sustainable and lucrative income. Shark News, 16, 8-9.

Hammerschlag, N., Gallagher, A. J., Wester, J., Luo, J., \& Ault, J. S. (2012). Don't bite the hand that feeds: assessing ecological impacts of provisioning ecotourism on an apex marine predator. Functional Ecology, 26(3), 567-576. 
Haskell, P. J., McGowan, A., Westling, A., Mendez-Jiménez, A., Rohner, C. A., Collins, K., Rosero-Caicedo, M., Salmond, J., Monadjem, A., Marshall, A. D., \& Pierce, S. J. (2014). Monitoring the effects of tourism on whale shark Rhincodon typus behaviour in Mozambique. Oryx, 1-8.

Higham, J. E., Bejder, L., Allen, S. J., Corkeron, P. J., \& Lusseau, D. (2016). Managing whalewatching as a non-lethal consumptive activity. Journal of Sustainable Tourism, 24(1), 1-18.

Higham, J. E. S., \& Lusseau, D. (2007). Urgent need for empirical research into whaling and whale watching. Conservation Biology, 21(2), 554-558.

Higham, J. E., \& Lusseau, D. (2008). Slaughtering the goose that lays the golden egg: Are whaling and whale-watching mutually exclusive?. Current Issues in Tourism, 11(1), 63-74.

Higham, J. E. S., \& Shelton, E. J. (2011). Tourism and wildlife habituation: Reduced population fitness or cessation of impact?. Tourism Management, 32(6), 1290-1298.

Hill, W., Byrne, J., \& Pickering, C. (2015). The 'hollow-middle': why positive community perceptions do not translate into pro-conservation behaviours in El Vizcaíno Biosphere Reserve, Mexico. International Journal of Biodiversity Science, Ecosystem Services \& Management, 11(2), 168-183.

Hunt, C., \& Stronza, A. (2011). Missing the forest for the trees?: incongruous local perspectives on ecotourism in Nicaragua converge on ethical issues. Human Organization, 20(4), 376-386.

Huveneers, C., Meekan, M. G., Apps, K., Ferreira, L. C., Pannell, D., \& Vianna, G. M. S. (2017). The economic value of shark-diving tourism in Australia. Reviews in Fish Biology and Fisheries, 27(3), 665-690.

Jacobs, M. H., \& Harms, M. (2014). Influence of interpretation on conservation intentions of whale tourists. Tourism Management, 42, 123-131.

Jiang, Y., Lück, M., \& Parsons, E. C. M. (2007). Public awareness, education, and marine mammals in captivity. Tourism Review International, 11(3), 237-249.

Juvan, E., \& Dolnicar, S. (2014). The attitude-behaviour gap in sustainable tourism. Annals of Tourism Research, 48, 76-95.

Juvan, E., Ring, A., Leisch, F., \& Dolnicar, S. (2016). Tourist segments' justifications for behaving in an environmentally unsustainable way. Journal of Sustainable Tourism, 24(11), 1506-1522. 
Lee, J. J. (2014, January 30). "Slaughterhouse said to process "horrifying” number of whale sharks annually.” Retrieved on January 20, 2018 from: https://news.nationalgeographic.com/news/2014/01/140129-whale-shark-endangered-citesocean-animals-conservation/

Li, W., Wang, Y., \& Norman, B. (2012). A preliminary survey of whale shark Rhincodon typus catch and trade in China: an emerging crisis. Journal of Fish Biology, 80(5), 1608-1618.

Lück, M. (2003). Education on marine mammal tours as agent for conservation-but do tourists want to be educated?. Ocean \& Coastal Management, 46(9), 943-956.

Matheny, G. (2006). Utilitarianism and animals, in: Singer, P. (Ed.), In defense of animals: The second wave, Blackwell Publishing, pp. 13-26.

Mayes, G., Dyer, P., \& Richins, H. (2004). Dolphin-human interaction: Pro-environmental attitudes, beliefs and intended behaviours and actions of participants in interpretation programs: a pilot study. Annals of Leisure Research, 7(1), 34-53.

Mehta, J. N., \& Kellert, S. R. (1998). Local attitudes toward community-based conservation policy and programmes in Nepal: a case study in the Makalu-Barun Conservation Area. Environmental Conservation, 25(4), 320-333.

Mintzer, V. J., Martin, A. R., da Silva, V. M., Barbour, A. B., Lorenzen, K., \& Frazer, T. K. (2013). Effect of illegal harvest on apparent survival of Amazon River dolphins (Inia geoffrensis). Biological Conservation, 158, 280-286.

Moorhouse, T. P., Dahlsjö, C. A., Baker, S. E., D'Cruze, N. C., \& Macdonald, D. W. (2015). The customer isn't always right - conservation and animal welfare implications of the increasing demand for wildlife tourism. PloS ONE, 10(10), e0138939.

Moorhouse, T., D’Cruze, N. C., \& MacDonald, D. W. (2017). Unethical use of wildlife in tourism: what's the problem, who is responsible, and what can be done? Journal of Sustainable Tourism, 25(4), 505-516.

Newsome, D., \& Rodger, K. (2008). To feed or not to feed: a contentious issue in wildlife tourism, in: Lunney, D., Munn, A., Meikle, W. (Eds.), Too close for comfort: contentious issues in human-wildlife encounters, Royal Zoological Society of New South Wales, pp. 255-270. 
Newsome, D., Lewis, A., \& Moncrieff, D. (2004). Impacts and risks associated with developing, but unsupervised, stingray tourism at Hamelin Bay, Western Australia. International Journal of Tourism Research, 6(5), 305-323.

O’Malley, M. P., Lee-Brooks, K., \& Medd, H. B. (2013). The global economic impact of manta ray watching tourism. PLoS ONE, 8(5), e65051.

Orams, M. B. (1996). Using interpretation to manage nature-based tourism. Journal of Sustainable Tourism, 4(2), 81-94.

Orams, M. (2002). Feeding wildlife as a tourism attraction: a review of issues and impacts. Tourism Management, 23(3), 281-293.

Packer, J., \& Ballantyne, R. (2012). Comparing captive and non-captive wildlife tourism. Annals of Tourism Research, 39(2), 1242-1245.

Parsons, E. C. M. (2012). The negative impacts of whale-watching. Journal of Marine Biology, 2012, 1-9.

Patroni, J., Simpson, G., \& Newsome, D. (in press). Feeding wild fish for tourism - a systematic quantitative literature review of impacts and management. International Journal of Tourism Research.

Pegas, F. de V., Coghlan, A., Stronza, A., \& Rocha, V. (2013). For love or for money? Investigating the impact of an ecotourism programme on local residents' assigned values towards sea turtles. Journal of Ecotourism, 12(2), 90-106.

Pierce, S. J., Méndez-Jiménez, A., Collins, K., \& Rosero-Caicedo, M. (2010). Developing a code of conduct for whale shark interactions in Mozambique. Aquatic conservation: Marine and Freshwater ecosystems, 20(7), 782-788.

Pierce, S. J., \& Norman, B. 2016. Rhincodon typus. The IUCN Red List of Threatened Species 2016: e.T19488A8913502.

Powell, R. B., \& Ham, S. H. (2008). Can ecotourism interpretation really lead to pro-conservation knowledge, attitudes and behaviour? Evidence from the Galapagos Islands. Journal of Sustainable Tourism, 16(4), 467-489.

Quiros, A. L. (2007). Tourist compliance to a Code of Conduct and the resulting effects on whale shark (Rhincodon typus) behavior in Donsol, Philippines. Fisheries Research, 84(1), 102-108. 
Raudino, H., Rob, D., Barnes, P., Mau, R., Wilson, E., Gardner S., \& Waples, K. (2016). Whale shark behavioural responses to tourism interactions in Ningaloo Marine Park and implications for future management. Conservation Science Western Australia, 10, 2.

Reynolds, P. C., \& Braithwaite, D. (2001). Towards a conceptual framework for wildlife tourism. Tourism Management, 22(1), 31-42.

Rizzari, J. R., Semmens, J. M., Fox, A., \& Huveneers, C. (2017). Observations of marine wildlife tourism effects on a non-focal species. Journal of Fish Biology, 91(3), 981-988.

Rowat, D., \& Brooks, K. S. (2012). A review of the biology, fisheries and conservation of the whale shark Rhincodon typus. Journal of Fish Biology, 80(5), 1019-1056.

Schleimer, A., Araujo, G., Penketh, L., Heath, A., McCoy, E., Labaja, J., Lucey, A., \& Ponzo, A. (2015). Learning from a provisioning site: code of conduct compliance and behaviour of whale sharks in Oslob, Cebu, Philippines. PeerJ, 3, e1452.

Semeniuk, C. A., Bourgeon, S., Smith, S. L., \& Rothley, K. D. (2009). Hematological differences between stingrays at tourist and non-visited sites suggest physiological costs of wildlife tourism. Biological Conservation, 142(8), 1818-1829.

Semeniuk, C. A., Haider, W., Beardmore, B., \& Rothley, K. D. (2009). A multi-attribute trade-off approach for advancing the management of marine wildlife tourism: a quantitative assessment of heterogeneous visitor preferences. Aquatic Conservation: Marine and Freshwater Ecosystems, 19(2), 194-208.

Sezer, O., Gino, F., \& Bazerman, M. H. (2015). Ethical blind spots: explaining unintentional unethical behavior. Current Opinion in Psychology, 6, 77-81.

Shani, A. (2009). Tourists' attitudes towards the use of animals in tourist attractions: an empirical investigation. Doctoral dissertation, University of Central Florida, Orlando, FL.

Singer, P. (1995). Animal liberation (2nd Edition). London: Pimlico.

Sorice, M. G., Shafer, C. S., \& Scott, D. (2003). Managing endangered species within the use/preservation paradox: understanding and defining harassment of the West Indian manatee (Trichechus manatus). Coastal Management, 31(4), 319-338. 
Spiteri, A., \& Nepal, S. K. (2006). Incentive-based conservation programs in developing countries: a review of some key issues and suggestions for improvements. Environmental Management, 37(1), 1-14.

Stem, C. J., Lassoie, J. P., Lee, D. R., Deshler, D. D., \& Schelhas, J. W. (2003). Community participation in ecotourism benefits: The link to conservation practices and perspectives. Society \& Natural Resources, 16(5), 387-413.

Tenbrunsel, A. E., Diekmann, K. A., Wade-Benzoni, K. A., \& Bazerman, M. H. (2010). The ethical mirage: a temporal explanation as to why we are not as ethical as we think we are. Research in Organizational Behaviour, 30, 153-173.

Tenbrunsel, A. E., \& Messick, D. M. (2004). Ethical fading: the role of self-deception in unethical behavior. Social Justice Research, 17(2), 223-236.

Thomson, J. A., Araujo, G., Labaja, J., McCoy, E., Murray, R., \& Ponzo, A. (2017). Feeding the world's largest fish: highly variable whale shark residency patterns at a provisioning site in the Philippines. Royal Society Open Science, 4, 170394.

Tisdell, C., \& Wilson, C. (2001). Wildlife-based tourism and increased support for nature conservation financially and otherwise: evidence from sea turtle ecotourism at Mon Repos. Tourism Economics, 7(3), 233-249.

Topelko, K. N., \& Dearden, P. (2005). The shark watching industry and its potential contribution to shark conservation. Journal of Ecotourism, 4(2), 108-128.

TripAdvisor. (2016). Oslob whale shark watching. Accessed on January 27, 2016 from https://www.tripadvisor.com/Attraction_Review-g3226128-d2572900-ReviewsOslob_Whale_Shark_Watching-Oslob_Cebu_Island_Visayas.html.

Vaske, J. (2008). Survey research and analysis: applications in parks, recreation, and human dimensions. State College, PA: Venture.

Vianna, G. M. S., Meekan, M. G., Pannell, D. J., Marsh, S. P., \& Meeuwig, J. J. (2012). Socioeconomic value and community benefits from shark-diving tourism in Palau: a sustainable use of reef shark populations. Biological Conservation, 145(1), 267-277.

Walpole, M. J., \& Goodwin, H. J. (2001). Local attitudes towards conservation and tourism around Komodo National Park, Indonesia. Environmental Conservation, 28(2), 160-166. 
Waylen, K. A., McGowan, P. J., \& Milner-Gulland, E. J. (2009). Ecotourism positively affects awareness and attitudes but not conservation behaviours: a case study at Grande Riviere, Trinidad. Oryx, 43(3), 343-351.

Wilson, C., \& Tisdell, C. (2003). Conservation and economic benefits of wildlife-based marine tourism: sea turtles and whales as case studies. Human Dimensions of Wildlife, 8(1), 49-58.

Young, E. H. (1999). Balancing conservation with development in small-scale fisheries: is ecotourism an empty promise?. Human Ecology, 27(4), 581-620.

Zeppel, H., \& Muloin, S. (2008a). Conservation benefits of interpretation on marine wildlife tours. Human Dimensions of Wildlife, 13(4), 280-294.

Zeppel, H., \& Muloin, S. (2008b). Conservation and education benefits of interpretation on marine wildlife tours. Tourism in Marine Environments, 5(2-3), 215-227. 